\title{
A Case Study of Liang Qichao’s Literary Creations and Translations From Localization Theory
}

\author{
KE Yi-man \\ South China Business College, Guangdong University of Foreign Studies, Guangzhou, China
}

\begin{abstract}
Intercultures play a crucial role in localization of translation. They are the essential reference resources for those who are translators as well as writers in their literary translation or creation. Translators contribute to the extension of source culture and in target culture by means of intercultures to form new localized cultural paradigms, which help writers to improve their creations. Liang Qichao’s literary creation was influenced by the literary paradigms he translated. Through the translation, he borrowed new literary paradigms from foreign languages and converted them into more acceptable ones in his literature. The paper, from the perspectives of localization and intercultures by Anthony Pym, analyzes the characteristics and interactions between Liang Qichao’s literary translation and literary creation.
\end{abstract}

Keywords: localization, literary translation, literary creation, Liang Qichao

\section{Introduction}

Liang Qichao (1873-1929) is one of the greatest ideologists, educators, historians, and litterateurs in China. Although he attached importance to political activities, he also wrote a lot of literary works. Liang has written collections of literary works including Collected Works of Yin Bing Shi (饮冰室合集), Collection of Speech (讲 演集), Collection of Poems (诗文集), Collection of Letters (书信集), The Introduction of Chinese History (中 国史叙论). He had translated Shibashiro's The Adventures of the Beauties, Jules Gabriel Verne's Two Year's Holiday, and short novels of others which greatly influenced his literary creation. Liang Qichao skillfully translated foreign language works into a new Chinese literary genre and became the initiator of Literary Revolution and Poetry Revolution which laid the initial foundation for the May Fourth Movement or the New Culture Movement. This paper, from the perspectives of localization and intercultures by Anthony Pym, explores the effects of Liang's translation and creation, and analyzes the characteristics and interactions between Liang Qichao's literary translation and literary creation.

\footnotetext{
Acknowledgment: This research is sponsored by Key Disciplines (English Language and Literature) Program of Guangdong 2016, South China Business College, Guangdong University of Foreign Studies (本文是广东外语外贸大学南国商学院 2016 年 广东省特色重点学科英语语言文学的阶段性成果).

KE Yi-man, Master, Assistant, South China Business College, Guangdong University of Foreign Studies, Guangzhou, China.
} 


\section{Localization and Intercultures}

Anthony Pym applied sociology into his translation studies and put forward the concept of "intercultures". Also, he used globalization of translation to present his idea of "localization".

Pym wrote in Method in Translation History that

Beliefs and practices found in intersections or overlaps of cultures, where people combine something of two or more cultures at once... Interculturality is not to be confused with the fact that many cultures can be found within the one society or political unit, nor with the fact that things can move from one culture to another... An unspecified number of translators can be seen as members of intercultures or as having some degree of interculturality. (Pym, 2007, p. 177)

He thought that "In this very practical sense, localization is the adaptation and translation of a text (like a software program) to suit a particular reception situation” (Pym, 2004, p. 1). In Exploring Translation Theories, Pym treated localization as one of paradigms of translation theories and thought translation is a part of localization, so he wrote: "Localization can involve a wide range of tasks; it usually concerns information technology and marketing, as well as language skills” (Pym, 2010, p. 121).

Localization and intercultures cannot be separated from each other. Intercultures, based on the multi-cultural environment, stressed the crucial role of translators in cultural translation. Translators localized the foreign works by combining them with the target culture during the translation. In the New Culture Movement of China, the domestic translators localized the foreign literatures to provide new literary forms and genres for Chinese literature. Liang Qichao tried to translate literary works from different foreign languages when he stayed in Japan and realized his goals that localized literary genres in China. The paper analyzes the influences of Liang Qichao's literary translation and creation with the help of Antconc and the Chinese Corpus online tool.

\section{Interactions Between Early Translation and Creation in Localization}

Interactions between translation and creation played a significant role in the localization of foreign literary paradigms. Liang Qichao translated western literary works in Japanese or English to grasp the literary and poetic genres to realize the political aspirations. At that time, most individuals were unfamiliar with the vernacular Chinese, so he used classical Chinese and vernacular Chinese in the translation at the same time to help others understand the western cultures and ideas. Based on his achievements, lots of writers and translators launched the New Culture Movement with localization methods and retained western poetic paradigms.

Liang's translation works were known as The Adventures of the Beauties and The Fifteen Heroes (that is, Two Year's Holiday); and the latter one was regarded as the first scientific work which was translated by our Chinese translator. In order to introduce some useful expressions into Chinese, he translated these works though he was unfamiliar with foreign languages and didn't translate the original version of these western literary outputs. Virtually, he obtained the knowledge of western expressions and used these language paradigms in the early translation and creation.

\section{Premodification (“.......的”)}

Example (1) Two Year's Holiday (trans. by Liang 1902)

[ST] For half an hour Briant and his companions kept on to southward along the foot of the cliff; then they reached the right bank of the stream.

[TT] 沿壁南下, 约半点钟, 达于溪水之石岸。 
Example (2) Two Year's Holiday (trans. by Liang 1902)

[ST] Soon the side lights, red and green, rose above the water, and the fact of their being seen together showed that the steamer was steering straight for the yacht.

[TT] 歇一会又看见一红一绿的两个灯光, 那船一定是向一条直线对正我们来的了。

In the early period of the New Culture Movement, writers and translators were trying to find a suitable writing style in the translation and creation. As a pioneer, Liang attempted to use different forms of premodification which have the same meaning like "zhi (之)" in classical Chinese and "de (的)" in vernacular Chinese in the same novel to express the original meaning, and attracted readers who were familiar with classical Chinese to learn the vernacular Chinese. In this way, opinions and decisions about the localization translation of him would be accepted.

\section{Modal Particles}

Example (3) Two Year's Holiday (trans. by Liang 1902)

[ST] “Yes, Gordon”, answered Briant, who had coolly resumed his place.

[TT] 武安慢慢的翻起身回答道: “不要紧哩, 俄敦。”

Example (4) The Isles of Greece (trans. by Liang 1902)

[ST] The mountains look on Marathon-

And Marathon looks on the sea;

[TT] 玛拉顿后啊, 山容缥组, 玛拉顿前啊, 海门环绕。

In his translation, Liang used modal particles to express the original meaning of dialogues, so readers could appreciate the translation easily for the reason that they said in this way. More examples about premodifications and modal particles can be found and we reach a statistic of expressions (see Table 1).

Table 1

Statistic of Premodifications and Modal Particles in the Original and Translation

\begin{tabular}{llllll}
\hline Expressions & $\begin{array}{l}\text { Number in } \\
\text { original }\end{array}$ & Percentage & $\begin{array}{l}\text { Number in } \\
\text { translation }\end{array}$ & Percentage & Note \\
\hline 1 Premodifications & 492 & $0.051 \%$ & 384 & $0.341 \%$ & \\
2 Modal particles & 34 & $0.380 \%$ & 78 & $0.373 \%$ & Including: 呀、啊、呢、呵、吧 \\
\hline
\end{tabular}

Liang kept essential information and omitted lots of unimportant details when he translated this western novel. When comparing the number of premodifications, percentage of the original is much lower than that in the translation though the number in the original is higher than the number in translation. This situation is also reflected in the usage of modal particles. For Chinese, we like to use modal particles in spoken language, so Liang just translated in this way to show the localization.

\section{Interrogative Sentence}

Example (5) Two Year's Holiday (trans. by Liang 1902)

[ST] But would the dangers that threatened the schooner grow less when the sun illumined the sky?

[TT] 但虽系天亮, 又怎么呢?

Example (6) Two Year's Holiday (trans. by Liang 1902)

[ST] Where had this water come from? From a leak?

[TT] 这水究竟从哪里来呢? 
In his translation, Liang used interrogative sentences with the vernacular Chinese to make sure the structural equivalence. Here we reach a statistic of interrogative sentences (see Table 2).

Table 2

Statistic of Interrogative Sentences in the Original Text and Translation

\begin{tabular}{lllll}
\hline & & Number & Percentage & Note \\
\hline 1 & Original text & 161 & $0.180 \%$ & Including: when, where, what, why, who, how \\
2 & Translation & 72 & $0.387 \%$ & Including: 什么, 怎么, 哪里, 哪些, 谁, 吗, 呢, 焉 \\
\hline
\end{tabular}

The data above indicate that Liang omitted lots of contents when he translated the novel compactly, but he used important expressions to keep the linguistic features. In the original text, author wrote down dialogue scenes to boost the development of the story. Liang also tried to use these interrogative sentences to arouse interests of readers and use this new expression to innovate writing way.

\section{Interactions Between Early Creation and Later Creation in Localization}

Liang translated western literary works in his early literary career and used expressions he've took in literary creation. His letters, poems, novels, and speeches show his distinctive writing styles with detail. The translating and writing style of him shifted from using classical Chinese and vernacular Chinese in the early period into using vernacular Chinese only. Hence, features of his literary creation from different periods will be discussed.

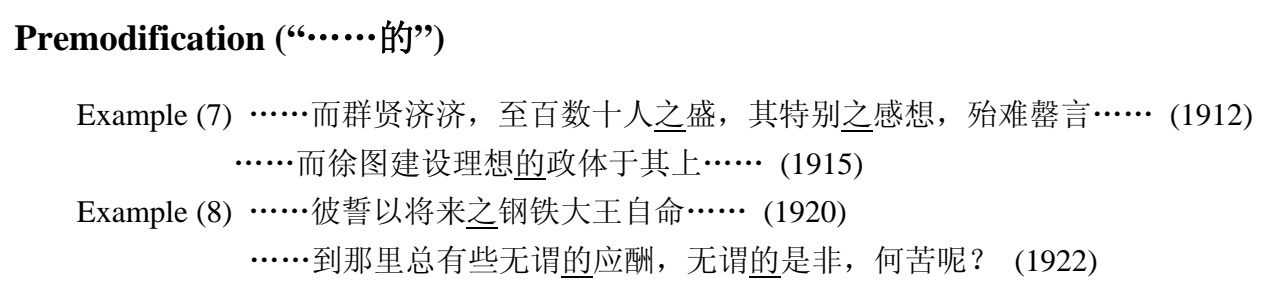

The usage of premodifications of “zhi (之)”, “de (的)” in Liang’s translation and creation is significant which shows the change of writing styles in his literary creations in different periods (see Table 3).

Table 3

Statistic of Premodification in the Creation

\begin{tabular}{lllllll}
\hline & & Number of Zhi & Percentage & Number of De & Percentage & Note \\
\hline 1 & Creation 1898-1919 & 3,474 & $5.484 \%$ & 54 & $0.085 \%$ \\
2 & Creation 1919-1923 & 489 & $0.955 \%$ & 2,168 & $4.236 \%$ \\
\hline
\end{tabular}

In compared with the usage of premodification, Liang used a great number of the classical Chinese character "zhi (之)" in his literary creation from 1898 to 1919. He expressed the cause that "although he intended to use the vernacular Chinese, it was difficult to translate it well. When he used the classical Chinese, translation became easier than ever” (Zhang, ed. 1999, p. 5674). So he chose to use the classical Chinese and vernacular Chinese at the same time in order to translate and create in a localized way. Liang used vernacular Chinese character “de (的)” after 1919 when the New Culture Movement had launched. 


\section{Modal Particles}

Example (9) ……我们四万万同胞啊, 快去革命罢: 赶紧革命罢! 大家都起来革命罢! (1902)

Example (10) ……诗是歌的笑的好呀? (1922)

One of the features of Liang's creations in different periods are modal particles. He used lots of modal particles in his translation and it affects his creations; but he also changed the using frequency of these words in the creation. Here we reach a statistic of modal particles (see Table 4).

Table 4

Statistic of Modal Particles in the Creation

\begin{tabular}{lllll}
\hline & & Number & Percentage & Note \\
\hline 1 & Creation 1898-1919 & 225 & $0.353 \%$ & Including: 啊, 哩, 呀, 呢, 吧, 罢, 哎, 啦 \\
\hline
\end{tabular}

The data indicate that the number of modal particles in creation is diminished after 1919. But when compared it with the using frequency in his translation, the number of modal particles is increased. The reason why he used these vocabularies is that he attracted readers in his political writings by using modal particles which were used frequently by citizens before 1919. Along with the New Culture Movement, he no longer needed to write political articles to inspire the common people. Worked as a translator and a writer, Liang gave priority to the requirement of Chinese readers and culture to promote his literary creation.

\section{Interrogative Sentence}

Example (11) ……他忽然跑去蒙古做甚么呢? 那里却有什么可图呢?
Example (12) ……怎么样他才会想我呢? (1922)

Interrogative sentence is one of the peculiar writing styles in Liang Qichao's literary creation. He changed the sentence patterns in an entirely new way after learning from the translation. Here we reach a statistic of interrogative sentence in his literary creations in various periods (see Table 5).

Table 5

Statistic of Interrogative Sentence in the Creation

\begin{tabular}{lllll}
\hline \multicolumn{1}{c}{ Number } & Percentage & Note \\
\hline 1 & Creation 1898-1919 & 540 & $0.864 \%$ & Including: 什么, 怎么, 哪里, 哪些, 谁, 几, 吗, 呢, 焉 \\
2 & Creation 1919-1923 & 368 & $0.736 \%$ & .
\end{tabular}

In fact, interrogative sentence is both commonly used in English and Chinese. In accordance with the statistic of interrogative sentence in his translation, he absorbed this expression and localized it in literary creation; the number of interrogative sentence in his works barely changed in different writing periods.

\section{Interactive Relations Between Translation and Creation}

Writers who also worked as translators were easily affected by their translation works, and the linguistic characters in writing altered as well. After analyzing linguistic paradigms in Liang Qichao’s literary translation and creation works, the writing styles and linguistic features he learned from translation in the early period 
impacted his creation for a long time. Liang, as an intercultural practitioner, tried his best to introduce western literature in China and localized them in traditional Chinese writing styles. In this way, he learned linguistic features and sentence patterns to inspire other writers who made progress in the New Culture Movement; what's more, further optimized Chinese literature. Therefore, his translation and creation languages reflect the translator utilized localization and intercultures to the translation; furthermore, it applied to the creation to realize the aim that integrates translation into Chinese literary works.

\section{Conclusion}

Localization and its intercultures influence the literary translation and creation at the same time. Person who works as a translator and a writer can build new literary paradigms and genres in his localized translation and creation. Liang Qichao made progress in literary translation and creation after learning from western literary works; with his help, the language form in Chinese writing shifted from the classical Chinese to the vernacular Chinese. In this way, translation and creation works of Liang Qichao contributed to Chinese literature and showed the mutual influence in literary works.

\section{References}

Li, H. X., \& Wu, J. X. (Eds.). (1984). Selected works of Liang Qichao. Shanghai: Shanghai People’s Publishing House. Liang, Q. C. (2011). Liang Qichao's letters. Xi'an: Shanxi Normal University General Publishing House Co., Ltd. Lin, W. G. (Ed.). (2009). Selected works of Liang Qichao. Chengdu: Sichuan Literature and Art Publishing House. Pym, A.(2004). The moving text: Localization, translation and distribution. Amsterdam: John Benjamins Publishing Company. Pym, A. (2007). Method in translation history. Beijing: Foreign Language Teaching and Research Press.

Pym, A. (2010). Exploring translation theories. London: Routledge.

Tang, Z. J., \& Tang, R. Z. (Eds.). (2018). Complete works of Liang Qichao (Vol. 17). Beijing: China Renmin University Press. Wang, X., \& Ji, F. (Trans.). (2009). Two year's holiday. Beijing: Tsinghua University Press.

Zhang, P. X. (Ed.). (1999). A collection of Liang Qichao's works (Vol. 10). Beijing: Beijing Publishing Group. 